\title{
Improving Students' Conceptual Mastery on Digital Circuit Topic Using Electronics Workbench Software
}

\author{
Islahudin ${ }^{1}$, Soeharto ${ }^{2}$ \\ Universitas Muhammadiyah Mataram, Indonesia ${ }^{1}$, University of Szeged, Hungary ${ }^{2}$ \\ islahudin.ntb@gmail.com¹, soeharto.soeharto@edu.u-szeged.hu²
}

Received: July $25^{\text {th }}, 2019$. Revised: October $22^{\text {nd }}, 2019$. Accepted: October $28^{\text {th }}, 2019$

Keywords:

Concept; Electronics

Workbench; Digital Circuits

\begin{abstract}
This study aims at improving the comprehension of digital circuit's concept by utilizing the electronic workbench software on the students of Physics Education Program, Muhammadiyah University of Mataram. The numbers of samples were 14 students who took Basic Electronics II course. The research design was Classroom Action Research. The study was conducted in two cycles. Each cycle consists of four stages of activity, namely Planning, Acting, Observing, and Reflecting. Technique of data analysis to determine the improvement of concept mastery in cycle 1 and cycle 2 was using the t-test formula. The results of data analysis obtained the classical passing grade in cycle 1 was $57.14 \%$ and cycle 2 was $85.71 \%$, so that the action was completed in cycle 2. The improvement in learning outcomes was included in the significant category because the t-test on the average of cycle 1 and cycle 2 showed the value of $t$ calculation $(=2.41297)>t$ distribution $(=2.145)$ so that $H_{0}<H_{a}$. Based on the results of this study it can be concluded that the use of electronics workbench software can improve the mastery of digital circuit's concept on the students of Physics Education Program, Muhammadiyah University of Mataram.
\end{abstract}

\section{INTRODUCTION}

The development of technology in the era of industrial revolution 4.0 has now entered all fields of life. This advancement certainly must be balanced with the graduate competencies of every college in order to be able to compete and survive. One of the courses relevant to this condition is Basic Electronics II. This course is offered in the fourth semester of the Physics Education Program, FKIP (Faculty of Teacher Training and Education), Muhammadiyah University of Mataram (UMMAT). This course consists of 4 credits with a distribution of 3 theoretical credits and 1 practicum credit so that lectures are conducted in the classroom and practicum activities are carried out in the laboratory. The implementation of lectures and practicum is a unit that cannot be separated. This means that the intellectual capacity of concepts or theories must also be balanced with practical activities. 
Based on the results of observations and documentation during the teaching of Basic Electronics II course, researchers got information that lecture activities and practicums were still not balanced especially in digital circuit material. In addition, the mastery of the digital circuit concept is still low

Concept is symbolizing an object to help someone understands and comprehends certain objects. A person's ability in grasping the symbols of object leads to the ability to master the concept [1]. The low mastery of concepts is due to the learning paradigm that is still teacher-centered learning. For this reason, it is necessary to change the paradigm towards the student-center learning [2]. One of alternatives to improve the mastery of concepts is to use a software simulation. Among the software simulations that can be applied are the Electronics Workbench (EWB) simulation program.

EWB (Electronics Workbench) is software from Interactive Image Technology Ltd. Electronics Workbench is the software for electronics. In the EWB there are a number of tools that can be applied in manufacturing digital electric circuits system [3-4]. Innovation in digital learning with EWB needs to be done, because through EWB it is expected that the students can accelerate the understanding of material and analytical skills, as well as designing digital circuits.

In the EWB software there is a menu of digital circuit that works in binary form, which is only in two circumstances. The output of circuit is in the state of low voltage or high voltage, there is no other output voltage rate allowed. This is called a logic system because they can be analyzed by Boole algebraic, so that, it forms a logic gate [5-7]. Logic gate is the basis of forming a digital electronic system that functions to convert one or more input signals into one logical output signal. The application of logic gates is as combinational logic circuit and sequential logic circuit [8]. Combinational logic circuits and sequential logic circuits have logic gates as basic components. Through these components, the circuit can think digitally, using binary logic. Each logic gate has a minimum of 2 (two) entries, except the BUFFER gate and the NOT gate. Both of these gates only have one input and one output [9].

Based on the facts above, the researchers conducted a classroom action research by utilizing electronic workbench software to improve the mastery of digital circuits' concept on the students of Physics Education Program, Muhammadiyah University of Mataram.

\section{METHOD}

This research is a classroom action research [8]. This research was conducted in two cycles. Each cycle consists of four stages of activity, namely Planning, Acting, Observing, and Reflecting. The subjects of this study were the students of classes 2017 and 2016 who took Basic Electronics lectures II in the even semester of Academic Year 2018/2019 with a total of 14 students who were taught directly by the researchers. To observe the improvement of concepts mastery in cycle 1 and cycle 2 , the t-test formula was used with the hypothesis as follows: $\mathrm{H}_{0}=$ there is no significant improvement between cycle 1 and cycle $2, \mathrm{H}_{\mathrm{a}}=$ there is a significant increase between cycle 1 and cycle 2 . The t-test equivalence used in the significance of cycles 1 and 2 employs the equation of [8]:

$$
t=\frac{M_{D}}{\sqrt{\frac{\sum x^{2} d}{N(N-1)}}}
$$

Remarks:

$\mathrm{d}_{\mathrm{i}}=$ difference of post-test score and pre-test score of each subject ( $\mathrm{i}$ )

$\mathrm{M}_{\mathrm{d}}=$ mean of gain $(\mathrm{d})$

$\mathrm{x}_{\mathrm{d}}=$ the deviation of gain score against the mean $\left(\mathrm{x}_{\mathrm{d}}=\mathrm{d}_{\mathrm{i}}-\mathrm{M}_{\mathrm{d}}\right)$

$\mathrm{x}^{2} \mathrm{~d}=$ square of the gain score deviation against the mean

$\mathrm{N}=$ number of samples (research subjects) 
Whereas to calculate the percentage of classical passing grade using the equation:

$$
P=\frac{\sum \text { Score } \geq \text { MPG }}{\sum \text { Number of test takers }} \times 100 \%
$$

Remarks:

$$
\mathrm{P}=\text { Percentages of Classical Passing Grade }
$$

The classical learning completeness is stated to be successful if the percentages of students who get a value of $\geq 70$ are more or equal to $85 \%$ of the total number of students. The results of this analysis are used as a reflection to conduct further planning in the next meeting and cycle. The results of the analysis are also used as a reflection in improving the learning design or even as a consideration in determining the appropriate learning method.

\section{RESULTS AND DISCUSSIONS}

The lectures on Basic Electronics II by utilizing EWB software to explain digital circuit material in this study were first carried out through cycle 1 . The lectures in the cycle 1 were conducted in four stages, namely planning, implementing actions, observing, and reflecting.

\section{Planning}

At the preparation stage the researchers prepared, among others, RPS (Learning syllabus) and RPP (Lesson Plan), textbooks, and electronics workbench (EWB) software as shown in Fig. 1 [3-4].

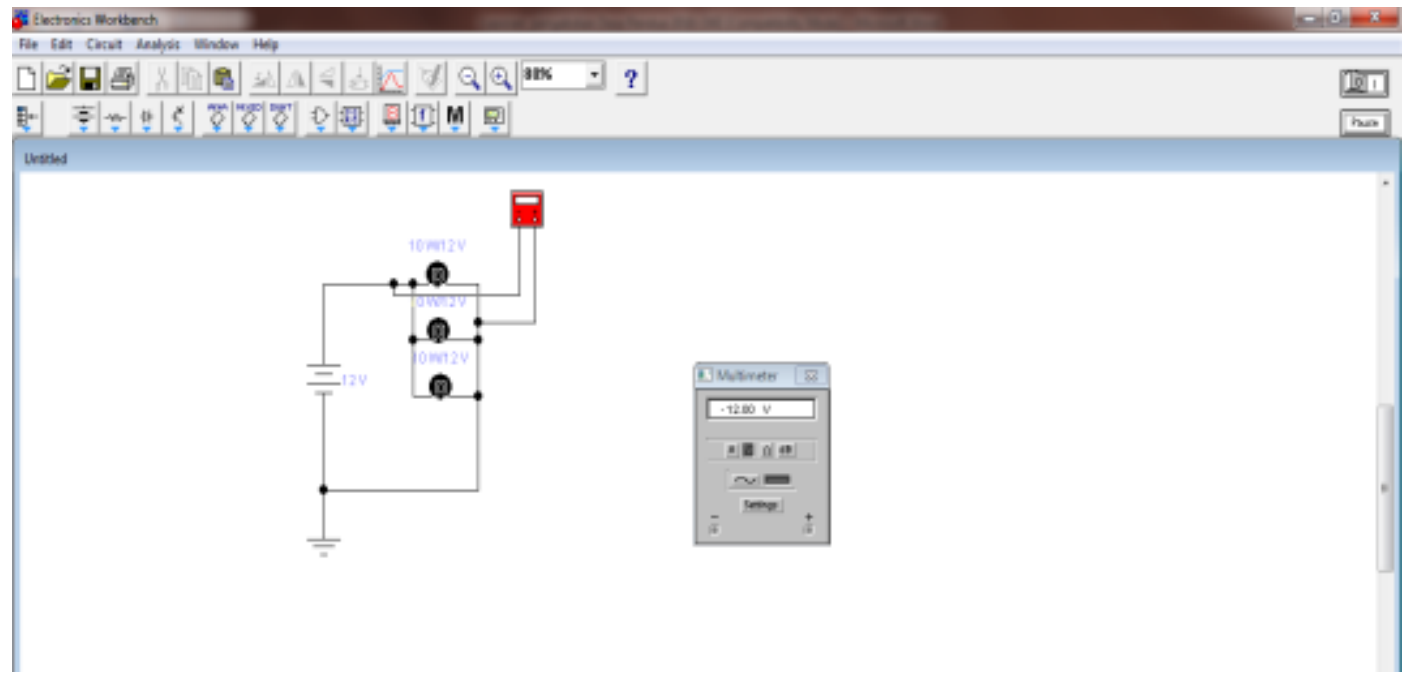

Fig.1 Display of electronics workbench software

\section{Implementing the action}

At the implementation stage, the lectures were carried out using lecturing, discussion and practice methods. The materials to be discussed are Boole algebra and OR, AND, NOT, NOR, NAND, and XOR logic gates. One of the logic gates compiled using EWB is shown in Fig. 2 


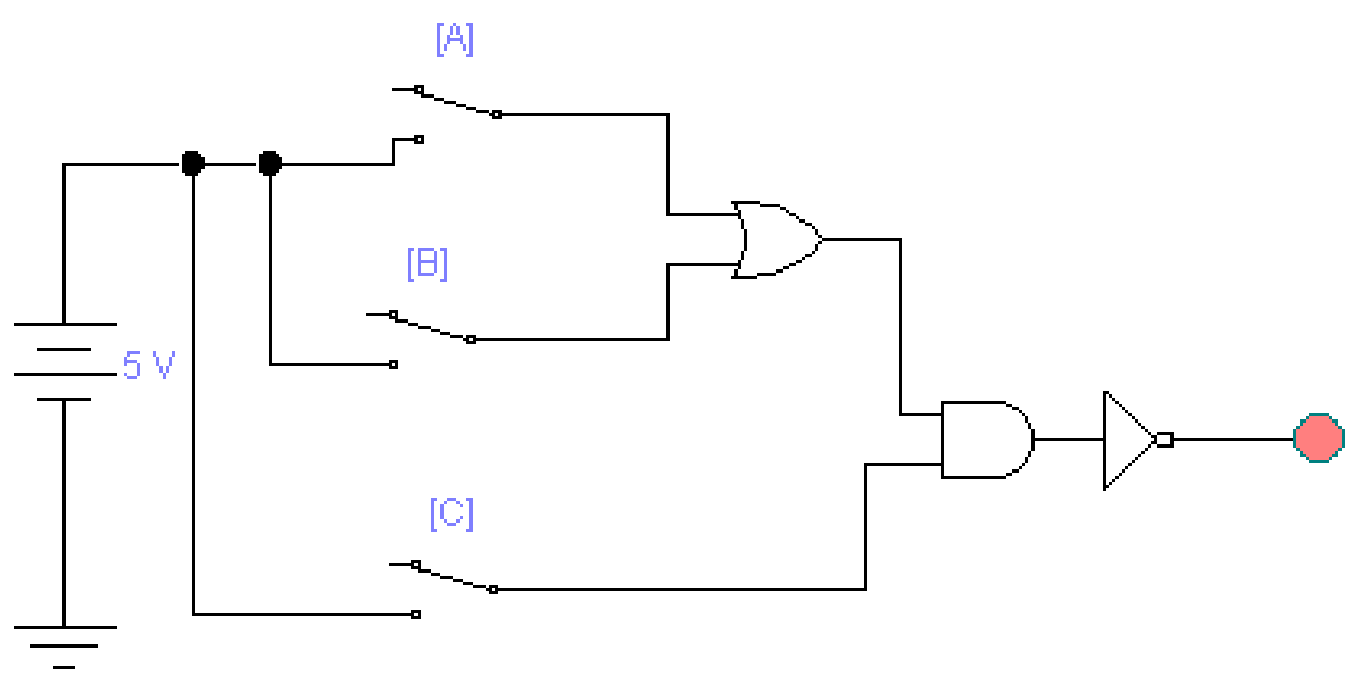

Fig 2. Boole algebra operation $\overline{(A+B) C}$

The circuit in Fig. 2 made the students easy to understand the digital circuits because the truth of Boole algebra operations can be proven directly by turning on the switch so that the LED light as an indicator can be ON or OFF. The researchers gave the exercises and discussed them together by using EWB software [10-11].

\section{Observing}

This stage was implemented through exercises or quizzes to measure the level of understanding of each student on the concept of logic gates using Boolean algebra. Data analysis performed on quiz results for obtaining information as the source of reflection.

\section{Reflection}

The results of reflection in the cycle 1 showed the numbers of students who got scores above 70 were $67.071 \%$, but it did not reach $85 \%$ so that the learning was categorized as fail or incomplete. This result is shown in Table 1.

Table 1. The Mastery of Digital Circuit Concept in Cycle 1

\begin{tabular}{cc}
\hline Category & Value \\
\hline Lowest score & 45 \\
The highest score & 76 \\
Average score & 67,071 \\
Classical completeness $(\%)$ & 57.14 \\
\hline
\end{tabular}

The cause of the incompleteness was because the students have not all fully understood the use of EWB software in assembling digital circuit components so that understanding concepts related to digital circuits is still in the low category. Based on these results, the activities of the classroom action research in cycle 1 was continued to cycle 2 to obtain a minimum passing grade of $85 \%$.

The implementation of the action in cycle 2 was carried out as an effort to improve the weakness of cycle 1 . In cycle 2, the steps taken were as same as the steps in the cycle 1, namely planning, implementing the actions, observing, and reflecting.

\section{Planning}

The planning stage included preparation of flip flop circuit material using EWB and supported by basic electronic II textbook. 


\section{Implementation}

In the implementation stage, the material being discussed was SR flip flop. Learning was done through the methods of discussion and query and response. The form of RS flip flop circuit using EWB software is shown in Fig 3.

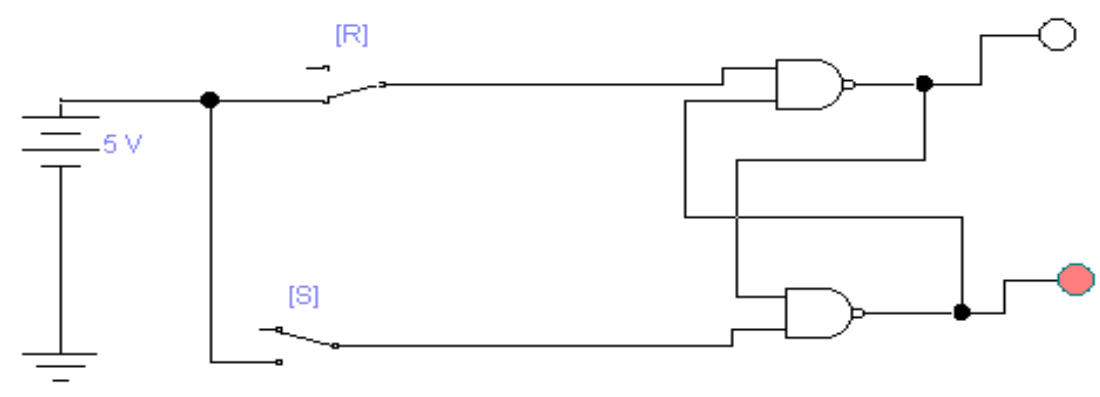

Fig 3. The Circuit of RS flip flop

Based on Fig. 3, the use EWB to assemble more complex digital circuits becomes easier. The Flip Flop RS circuit above can be verified to match Boole algebra as shown in Table 2.

Table 2. The Truth of RS flip flop through NAND Gate

\begin{tabular}{ccc}
\hline Set & Reset & Output \\
\hline 1 & 1 & $\mathrm{Q}$ (unchanged) \\
0 & 1 & $\mathrm{Q}=0 ; \mathrm{Q}^{\prime}=1$ \\
1 & 0 & $\mathrm{Q}=1 ; \mathrm{Q}^{\prime}=0$ \\
0 & 0 & uncertain \\
\hline
\end{tabular}

It appears that when reset is made to condition 1 and set to conditions 0 , the output is $Q=1$ and $Q^{\prime}=$ 0 . This result provides information that Fig. 3 corresponds to Table 2. After the SR flip flop material is discussed, the next material is clock flip flop RS. Learning was done through exercise and query and response methods. The shape of clock flip flop RS using the EWB software is shown in Fig. 4.

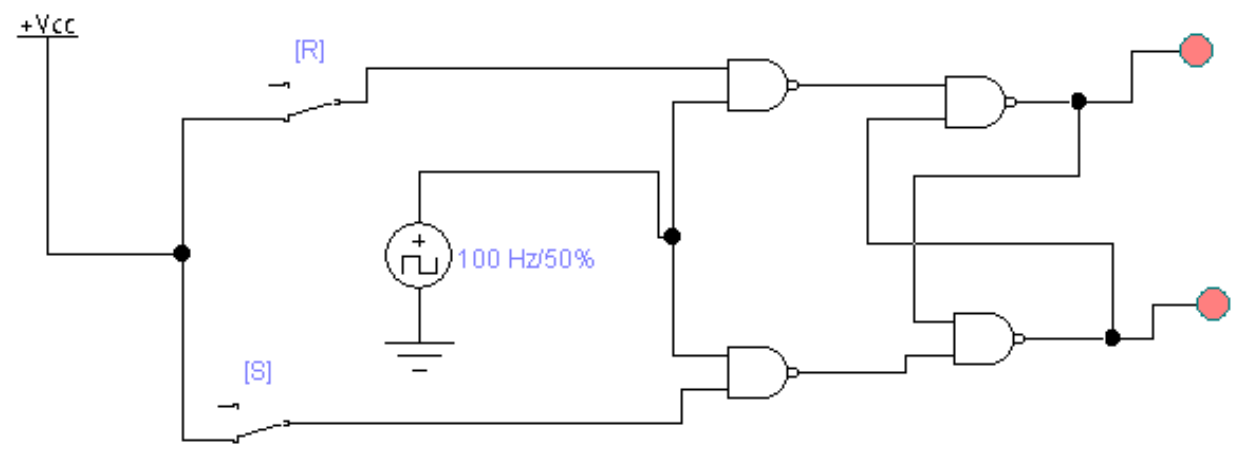

Fig 4. RS flip flop circuit with clock

Based on Fig. 4, there is an SR flip-flop that is activated with clock. The clock given is in the form of a square wave that will affect the output at Q and Q '. Figure 3.4 shows the SR flip flop commanded by the side to the positive of the clock pulse. Flip Flop will change the condition only if a signal is given to its input clock to make a transition from 0 to 1 . The $S$ and $\mathrm{R}$ inputs control the FF condition in the same way as described in the basic SR FF (without 
clock), but the FF will not respond to these inputs until the upside transition occurs from the clock pulse [12-13]. Whereas the truth is shown in Table 3.

Table 3. The Truth for SR Flip-Flop with clock

\begin{tabular}{cccccc}
\hline & Input & \multicolumn{4}{c}{ Output } \\
\hline Set & Reset & Clock & Q & Q' & Result \\
\hline 0 & 0 & - & Q & Q' & Unchanged \\
0 & 1 & - & 0 & 1 & RESET \\
1 & 0 & - & 1 & 0 & SET \\
1 & 1 & $\uparrow$ & $?$ & $?$ & Uncertain \\
\hline
\end{tabular}

The clock application on the SR Flip-Flop appears in the pulse shape display Fig. 5.

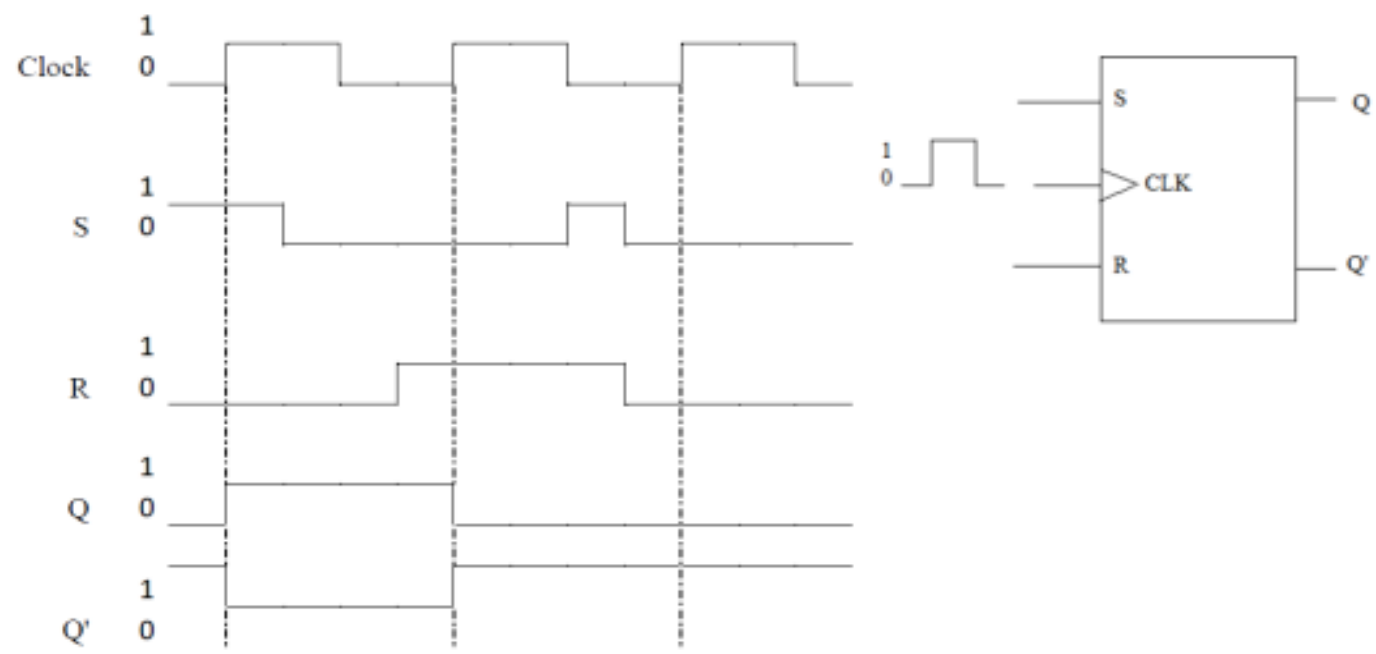

Fig 5. The RS flip flop output waveform with clock

Based on Fig. 5, it can be seen that FF output is not affected by the side towards the negative of the clock pulse. It is also noted that $\mathrm{S}$ and $\mathrm{R}$ levels have no effect on FF except when there is a positive transition from the clock pulse [14]. The $\mathrm{S}$ and $\mathrm{R}$ inputs are essentially controller inputs, which control which FF output is in the event of a clock pulse. Clock input is a trigger input, which actually causes changes in FF conditions according to the levels of $\mathrm{S}$ and $\mathrm{R}$ inputs [15].

\section{Observing}

At the observation stage, the researchers provided an exercise questions or quiz related to Flip Flop material. The quiz results were then analyzed as shown in Table 4.

Table 4. The mastery of Digital Circuits Concept of Cycle 2

\begin{tabular}{cc}
\hline Category & Value \\
\hline Lowest score & 68 \\
Highest score & 78 \\
Average score & 72,857 \\
Classical completeness $(\%)$ & 85.71 \\
\hline
\end{tabular}

Based on Table 4, it appears that the average value in the second cycle increased to 72,857 compared to the cycle 1 . The classical completeness also increased to $85.71 \%$. This increase was due to the students' mastery on digital circuit's concepts was getting higher through the use of electronics workbench software. An increase in understanding of this concept is following the results of community service regarding the installation of electric switch lamps in households using the EWB (Electronics Workbench) concept for SMKN 1 Batukliang Utara North Aik Beriq Village Batukliang 
Utara District center of Lombok 2017. Training Using the concept of EWB (Electronics Workbench) greatly helps participants in understanding electrical applications in electrical installations in the household [3].

\section{Reflecting}

Classical completeness was $85.71 \%$ obtained from the number of students who scored above 70 were 12 people. This showed that the mastery of students on the concept of digital circuits, especially on flip flop material, was getting higher with the use of EWB software. Therefore, the action was stopped in the cycle 2 . This is by better student learning outcomes after being given treatment in their learning using the Electronics WorkBench (EWB) learning media. The availability of the media supporting learning, minimal inhibiting the creation of effective learning activity. To overcome the lack of availability of laboratory tools at SMK Muhammadiyah Kradenan electric circuit experiments especially in dynamic, used software called Electronic Workbench 5.12 developed in is categorized. The method in this research is R\&D. Order categorized created contains an introduction, a summary of the dynamic electrical material, guide students do practical applications using EWB, bibliography of references that have been used in the preparation of categorized as well as profile the application of EWB. Feasibility test and analysis of readability stated that is categorized as very viable to use and easy to understand. Cognitive value analysis results using test students gain obtained an increase of 0.21 low criteria. The value of the character of the discipline, communicative, curiosity, creative and start expanding at an increase of 0.13 berkriteria low. Analysis results can be drawn conclusions if categorized media assisted can improve cognitive values and character but not significantly [2].

Significant value of the mastery improvement on the concept of digital circuits in cycle 1 and cycle 2 based on table 1 and table 2, the mastery improvement of digital circuits' concept can be significantly calculated using the $t$ test [8]. The results of test is shown in table 5

Table 5. Significance of Digital Circuits Concepts Mastery in Cycle 1 and Cycle 2

\begin{tabular}{ccc}
\hline Category & Value & Value \\
\hline Lowest score & 45 & 68 \\
Highest score & 76 & 78 \\
Average score & 67,071 & 72,857 \\
Classical completeness (\%) & 57.14 & 85.71 \\
Significance of t-test & & 2.41297 \\
\hline
\end{tabular}

Based on Table 5 and the list of $t$ test tables [9] obtained the value of $t$ calculation $(=2.41297)>t$ distribution $(=2.145)$ at the confidence level of $95 \%$. This shows that the mastery of digital circuit's concept with the use of electronics workbench software significantly increased between cycle 1 and cycle 2. The results in Table 5 are shown in Fig 6.

Based on Fig. 6 it was found that the mastery of concept was more improved in the material of digital circuit by utilizing the electronics workbench software. This significant increase in mastery of concepts was caused by the electronics workbench software facilitated the students in corresponding between theory and practice [16]. This is because at the same time each theory to be studied was directly examined for its truth without having to do any practicum in the laboratory. These results are in accordance with research on the utilization of EWB-based virtual laboratory (Electronics Workbench) towards improvement of physics learning outcomes of class XII IPA MA NW Darussalimin Sengkol students, Batukliang, Lombok Tengah 2018 Academic Year. Based on the results of the study it can be concluded that there is a significant influence on the use of virtual laboratories based on EWB (Electronics Workbench) on the improvement of physics learning outcomes for students of class XII MA Darussalimin NW Sengkol, Batukliang, Center of Lombok 2018/2019 academic year and in the medium category [4]. The positive impact of this research is to provide an increase in understanding of student concepts on a digital circuit material. This is consistent with the results of previous studies that have to do with the use of electronics workbench software. 


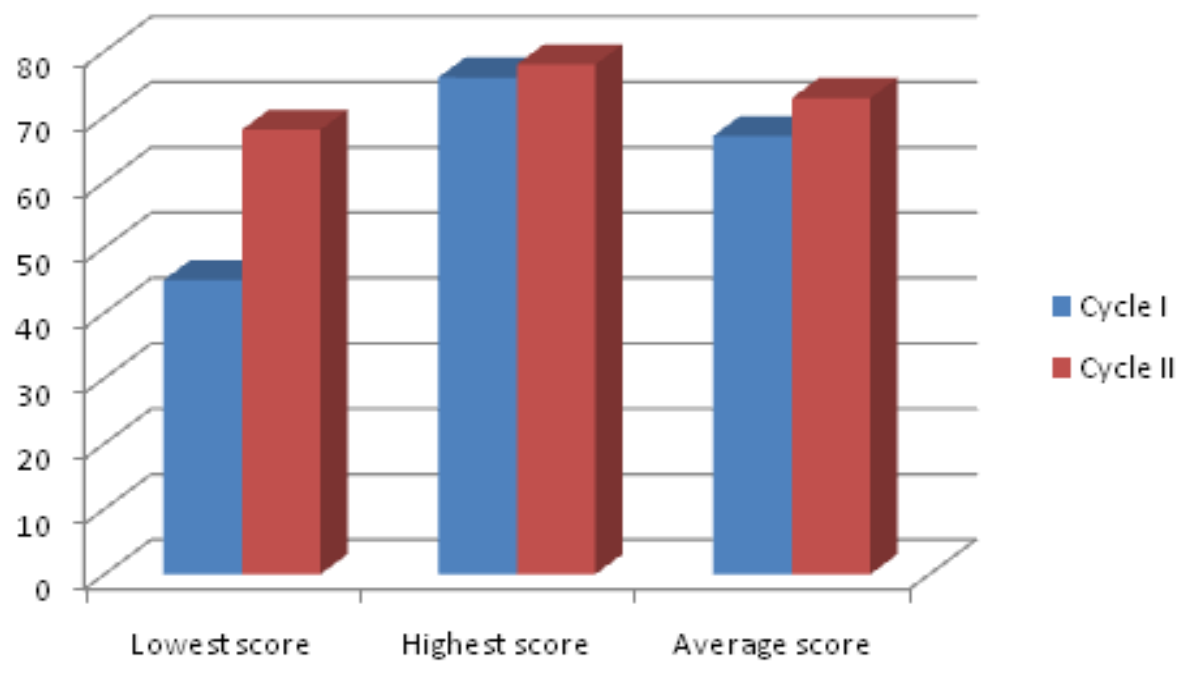

Fig 6. Chart of the mastery of digital circuit's concept in cycle 1 and cycle 2

An increase in understanding of this concept is due to the electronics workbench software can be operated in accordance with the actual digital circuit. In addition, the electronics workbench software can be operated to check the correctness of the circuit so that the fault is detected.

\section{CONCLUSION AND SUGGESTION}

\section{Conclusion}

Based on the results of the study, it can be concluded that the use of the electronics workbench software can improve the mastery of students' concepts on digital circuit material. It can be seen from the classical completeness obtained in cycle 1 namely $57.14 \%$ and cycle 2 was $85.71 \%$, so that; the action was completed in cycle 2 . The increase in learning outcomes was included in the significant category because the t-test of the average difference between the results in cycle 1 and cycle 2 showed the value of $t_{\text {calculation }}(=2.41297)>t$ distribution $(=2.145)$ at the confidence level of $95 \%$.

\section{Sugestion}

The suggestion that can be conveyed is that the necessity to do further research on the use of the electronics workbench software in other electronic materials.

\section{ACKNOWLEDGMENTS}

The researchers express their gratitude to LPPM of Muhammadiyah University of Mataram on the support given to this research so that the research can be smoothly and punctually accomplished.

\section{REFERENCES}

[1] Kusairi, S. (2013). Pengaruh Blended Learning terhadap Penguasaan Konsep dan Penalaran Fisika Peserta Didik Kelas X. Jurnal Pendidikan Fisika Indonesia, 9(1).

[2] Setiawan, R., \& Susilo, S. (2017). Pengembangan LKS Berbantuan Media Electronic Workbench untuk Meningkatkan Nilai Karakter Siswa pada Bahasan Listrik Dinamis. UPEJ Unnes Physics Education Journal, 6(3): 59-64.

[3] Islahudin, I., \& Sabaryati, J. (2018). Pelatihan Pemasangan Lampu Listrik Bersaklar Di Rumah Tangga Menggunakan Konsep EWB (Electronics Workbench) Bagi Siswa SMKN I Batu 
Kliang Utara Desa Aik Beriq Kecamatan Batu Kliang Utara Kabupaten Lombok Tengah Tahun 2017. SELAPARANG Jurnal Pengabdian Masyarakat Berkemajuan, 1(2): 5-8.

[4] Islahudin, I., Khaerani, S., \& Zulkarnain, Z. (2018). Pemanfaatan Laboratorium Virtual Berbasis Ewb (Electronics Workbench) Terhadap Peningkatan Hasil Belajar Fisika Siswa IPA Kelas XII IPA Ma NW Darussalimin Sengkol, Batukliang Lombok Tengah Tahun Pelajaran 2018/2019. ORBITA: Jurnal Kajian, Inovasi dan Aplikasi Pendidikan Fisika, 4(2): 47-51.

[5] Islahudin. (2018). Buku Ajar Elektronika Dasar Lanjutan, ISBN: 9786237022640 . Yogyakarta: Deepublish.

[6] Putro, S. S. (2015). Pemanfaatan Aplikasi Electronic Workbench (EWB) Pada Mata Kuliah Logika Informatika Materi Gerbang Logika. Seminar Nasional Teknologi Pendidikan UM: 336345.

[7] Rompis, L. (2017). Perancangan Rangkaian Digital Pendeteksi Kontinuitas Saluran Transmisi. Prosiding Seminar Nasional Teknik Elektro (FORTEI 2017) ISBN 978-602-6204-24-0 Fakultas Teknik Universitas Negeri Gorontalo: 117-120.

[8] Islahudin, I., \& Yulaika, R. (2019, February). Penerapan Pendekatan Kontekstual Berbantuan Buku Ajar Untuk Meningkatkan Hasil Belajar Fisika Siswa Kelas X MIPA 1 SMAN 1 Labuapi Semester Gasal Tahun Pelajaran 2018/2019. In Prosiding Seminar Nasional II APPPI NTB 2018 (Vol. 1, No. 1).

[9] Riduwan. (2013). Metode dan Teknik Menyusun Tesis. Bandung: Alfabeta.

[10] Triyani, L., Islahudin, I., \& Darmayanti, N. W. S. (2019). Pengembangan Media Pembelajaran Kalseg Fisika Untuk Meningkatkan Pemahamn Konsep Siswa Kelas X Materi Usaha. ORBITA: Jurnal Kajian, Inovasi dan Aplikasi Pendidikan Fisika, 5(1): 33-44.

[11] Wahyu, Y. D., Islahudin, I., \& Zulkarnain, Z. (2018). Analisis Kemampuan Mahasiswa Menentukan Persamaan Hukum Newton Di Program Studi Pendididkan Fisika Universitas Muhammadiyah Mataram Tahun 2017. ORBITA: Jurnal Kajian, Inovasi dan Aplikasi Pendidikan Fisika, 4(1): 28-37.

[12] Darmayanti, N. W. S., \& Utami, L. S. (2018). Analisis Kemampuan Mahasiswa Angkatan 2016 Prodi Fisika dalam Membuat Tes Hasil Belajar Fisika Aspek Kognitif pada Mata Kuliah Evaluasi Pembelajaran Fisika. ORBITA: Jurnal Kajian, Inovasi dan Aplikasi Pendidikan Fisika, 4(2): $1-5$.

[13] Jannah, Z. B., Islahudin, I., \& Darmayanti, N. W. (2018). Pengembangan Modul Fisika Bilingual Materi Hukum Newton Pada Siswa SMA Kelas X Untuk Meningkatkan Motivasi Belajar Fisika Tahun Ajaran 2017/2018. ORBITA: Jurnal Kajian, Inovasi dan Aplikasi Pendidikan Fisika, 4(2): 37-46.

[14] Islahudin, I., Sabaryati, J., Zulkarnain, Z., Khaerani, S., Pathoni, H., \& Idris, K. (2019). Pelatihan Merangkai Komponen Rangkaian Listrik Dengan Metode "DEBU"(Demonstrasi, Bahas, dan Unjuk Kerja) Bagi Guru Fisika Di Desa Aik Dareq, Kecamatan Batukliang, Lombok Tengah Tahun 2019. SELAPARANG Jurnal Pengabdian Masyarakat Berkemajuan, 2(2): 33-36.

[15] Angraini, L. M., Sudiarta, I. W., Qomariyah, N., Alaa, S., \& Handayana, I. G. N. Y. (2019). Peningkatan Kompetensi Komputasi Fisika Dan Kimia Untuk Mahasiswa Program Studi Fisika Fmipa Universitas Mataram. SELAPARANG Jurnal Pengabdian Masyarakat Berkemajuan, 2(2): $37-41$.

[16] Islahudin, I., \& Nizaar, M. (2017). Pengembangan Sensor Koil Datar 3-D untuk Deteksi Gempa Dini di Wilayah Lombok. Jurnal Nasional Teknik Elektro dan Teknologi Informasi, 6(1): 84-92. 